\title{
Corn Stalk Response to Plant Population and the Bt-European Corn Borer Trait
}

\author{
Trenton F. Stanger* and Joseph G. Lauer
}

\begin{abstract}
Current research indicates that plant populations should increase above the current Wisconsin recommendation of 74100 plants ha $^{-1}$ for higher corn (Zea mays L.) grain yields. However, stalk lodging is a major constraint to increasing plant populations. One option growers have is using Bt (Bacillus thuringiensis) hybrids, which are known to lodge less. A new method for assessing stalk lodging risk is needed. The objectives of this study were to (i) assess rind strength of corn hybrids with or without the $\mathrm{Bt}$ trait to increasing plant populations at natural levels of European Corn Borer [ECB, Ostrinia nubilalis (Hübner)], and (ii) determine the potential of rind strength measurements for predicting stalk lodging. In 2003 and 2004, rind penetrometer resistance (RPR) was used to measure rind strength for four Bt and five non-Bt hybrids with plant populations ranging from 64220 to 123500 plants ha ${ }^{-1}$ at 10 locations in Wisconsin. Stalk lodging increased from 6 to $18 \%$ as plant population increased, and only at one location, Arlington, did Bt hybrids lodge significantly less (20 vs. $42 \%$ ) than non-Bt hybrids. The RPR of both Bt and non-Bt hybrids decreased from 3.9 to 3.7 load-kg plant $^{-1}$ with increasing plant population. Plants with rind strength measurements $<3.9$ load-kg plant $^{-1}$ taken at physiological maturity showed more lodging. Thus, such measurements appear to be a good indicator of stalk lodging potential in a high plant population situation. This new method has potential to help growers prepare for grain harvest by identifying fields with plants having average RPR below a 3.9 load-kg plant ${ }^{-1}$ threshold, and adjusting harvest schedules of suspect fields earlier to avoid yield losses caused by stalk lodging. Further research using more hybrids across a range of environmental conditions and plant populations will be necessary to fully understand the importance of this tool and its potential importance in understanding and identifying high lodging potential environments.
\end{abstract}

$I^{\top}$ N MODERN CORN PRODUCTION, lodging is still a major constraint to maximizing grain yields (Sibale et al., 1992a), along with barrenness (Troyer and Rosenbrook, 1983) and reduced ear sizes and kernel weights (Monneveux et al., 2005). Lodging can increase significantly with high plant populations (Moentono et al., 1984; Thomison and Jordan, 1995; Jampatong et al., 2000; Pedersen and Lauer, 2002; Bruns and Abbas, 2005; Stanger and Lauer, 2006). Greater lodging at high plant populations may result in heavy harvest losses that eliminate any yield increase that may have occurred with the higher plant population (Olson and Sander, 1988). The potential for increased lodging at high plant populations is a deterrent for recommending harvest populations for grain corn much above 74100 plants ha $^{-1}$ (Cox, 1997).

Dep. of Agronomy, Univ. of Wisconsin, 1575 Linden Dr., Madison, WI 53706. Funded by CSREES project WIS0 142-4897. Received 16 Mar. 2006.*Corresponding author (tnt.stanger@gmail.com).

Published in Agron. J. 99:657-664 (2007).

Corn

doi:10.2134/agronj2006.0079

(c) American Society of Agronomy

677 S. Segoe Rd., Madison, WI 53711 USA

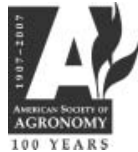

Since 1996, several seed companies have commercialized new transgenic corn hybrids resistant to ECB (Seydou et al., 2000). These hybrids have been genetically engineered to incorporate genes of Bt (Koziel et al., 1993; Armstrong et al., 1995), a toxin effective against larvae from both first and second ECB generations.

Lauer and Wedberg (1999) compared initial Bt corn hybrid introductions to standard adapted hybrids in the northern U.S. Corn Belt under different levels of ECB infestation. They concluded that stalk lodging was greater in the high-yielding standard hybrids compared with the Bt hybrids (7 vs. 3\%, respectively). Graeber et al. (1999) compared Bt hybrids to non-Bt hybrids and concluded that the $\mathrm{Bt}$ hybrids reduced or eliminated first and second generation damage caused by ECB and had decreased stalk lodging.

However, corn management systems must be justified on the basis of economic returns rather than on crop yield alone (VanGessel et al., 1995). According to Stanger and Lauer (2006), Bt corn yielded 7\% greater and had $22 \%$ less lodging than non-Bt corn, but the yield and lodging benefits of $\mathrm{Bt}$ hybrids were offset by the higher seed and harvest costs which resulted in no economic benefit due to using Bt corn.

Selection for better stalk quality in corn has remained important because of increased plant populations, rates of $\mathrm{N}$ fertilization, and grain drying costs. Fuel costs for artificially drying grain are subject to wide market fluctuations based on supply and political factors. High natural gas and liquefied propane gas prices may curtail future investments into artificial grain drying and reduce the amount of drying done at current installations. Therefore, the incidence of field-drying of corn grain may increase (Bruns and Abbas, 2004). Greater stalk strength reduces field-lodging losses arising from delayed harvest because of wet weather or planned longer field drying time, and selection for higher stalk crushing strength reduces the adverse effect of plant population on stalk lodging resistance (Moentono et al., 1984).

Genotypes that have high stalk strength must be identified by using rapid and simple screening techniques. Chemical, anatomical, and morphological characteristics of stalk composition are heritable and related to stalk lodging resistance (Foley and Clark, 1984; Berzonsky et al., 1986). However, chemical, anatomical, and morphological characteristics have limitations, and breeders need to develop more efficient and economical methods of selection (Sibale et al., 1992b).

Much of the strength of a corn stalk comes from the outside portion, the rind. Rind strength can be easily measured as the force required to puncture the rind with a needle of a rind penetrometer (Sibale et al., 1992a;

Abbreviations: Bt, Bacillus thuringiensis; ECB, European corn borer; $\mathrm{RPR}$, rind penetrometer resistance. 
Chesang-Chumo, 1993; Masole, 1993). The modified electronic rind penetrometer is considered a simpler and more rapid device to aid in selection of superior stalk strength than a manual penetrometer or an automated hydraulic press (Sibale et al., 1992a).

Previous research with Missouri Second Cycle Stiff Stalk Synthetic (MoSCSSS) has shown a correlation between improved stalk lodging resistance and increased RPR. Chesang-Chumo (1993) showed that RPR measurements were highly correlated with stalk lodging resistance, and there was a proportional decrease in stalk lodging with high RPR. Jampatong et al. (2000) and Martin et al. (2004) reported that stalk lodging percentage was negatively correlated with RPR. Martin et al. (2004) indicated that selection for RPR can significantly affect stalk lodging percentage, increasing or decreasing its occurrence. The objectives of this study were (i) to assess rind strength of corn hybrids with or without the Bt trait to increasing plant populations at natural levels of $\mathrm{ECB}$, and (ii) to determine the potential of rind strength measurements for predicting stalk lodging potential.

\section{MATERIALS AND METHODS}

Experiments were conducted in 2003 and 2004 at 10 locations in Wisconsin. Trial locations were chosen to represent the diverse soil and climatic conditions of the state of Wisconsin. The locations were grouped into three relative maturity production zones. All locations were managed according to recommended commercial production practices for maximizing grain yield. A detailed description of soil characteristics and cultural practices at each location can be found in a companion paper (Stanger and Lauer, 2006).

Two factors were evaluated: corn hybrid and plant population. Corn hybrids ranged from full-season to shorter-season maturity for their respective zones and were classified using the Minnesota Relative Maturity Rating (Table 1). All hybrids were selected based on the idea of using the best adapted

Table 1. Corn hybrids tested at three Wisconsin production zones during 2003 and 2004.

\begin{tabular}{|c|c|c|c|c|}
\hline Zone & Year & Hybrid & Trait & $\mathbf{M N} \mathbf{R M} \dagger$ \\
\hline \multirow[t]{7}{*}{ Southern zone $\$$} & \multirow[t]{4}{*}{2003} & Pioneer 37R71 & Bt§ & $99 \mathrm{~d}$ \\
\hline & & Renk RK622 & non-Bt & $100 d$ \\
\hline & & Pioneer 34M95 & & $109 d$ \\
\hline & & Pioneer 34M94 & non-Bt & $109 d$ \\
\hline & \multirow{3}{*}{2004} & Pioneer 34M95 & Bt & $109 d$ \\
\hline & & Pioneer 34M94 & non-Bt & $109 d$ \\
\hline & & Jung HDS104 & non-Bt & $106 d$ \\
\hline \multirow{6}{*}{ South Central zone } & \multirow{4}{*}{2003} & Pioneer 37R71 & Bt & $99 \mathrm{~d}$ \\
\hline & & Renk RK622 & non-Bt & $100 \mathrm{~d}$ \\
\hline & & Dekalb DKC5018 & & $100 \mathrm{~d}$ \\
\hline & & Dekalb DKC5143 & non-Bt & $100 \mathrm{~d}$ \\
\hline & \multirow[t]{2}{*}{2004} & Dekalb DKC5018 & & $100 \mathrm{~d}$ \\
\hline & & Dekalb DKC5143 & non-Bt & $100 \mathrm{~d}$ \\
\hline \multirow[t]{6}{*}{ North Central zone } & \multirow[t]{4}{*}{2003} & Pioneer 37R71 & & 99 d \\
\hline & & Renk RK622 & non-Bt & $100 \mathrm{~d}$ \\
\hline & & NK Brand N3030Bt & & $93 \mathrm{~d}$ \\
\hline & & NK Brand N3030 & non-Bt & $95 d$ \\
\hline & \multirow[t]{2}{*}{2004} & NK Brand N3030Bt & & $93 \mathrm{~d}$ \\
\hline & & NK Brand N3030 & non-Bt & $95 d$ \\
\hline
\end{tabular}

$\dagger$ Minnesota relative maturity rating.

$\ddagger$ Southern zone $=$ Arlington, Janesville, and Lancaster; South Central zone $=$ Fond du Lac, Galesville, and Hancock; North Central zone $=$ Chippewa Falls, Marshfield, Seymour, and Valders.

$\S$ All Bt hybrids were Yieldgard ECB. genetics available for the time of the experiment. Using multiple hybrids allowed us to sample from a wider range of genetics and environments, location or year. To provide consistency across years, a group of hybrids for each zone were chosen that were closely related (Table 1 ). The only difference between these hybrids was the Bt (Yieldgard ECB) trait. Specific hybrids will not be discussed in this paper because the focus was on differences between Bt and non-Bt corn. For the analysis, hybrids were considered random and nested within $\mathrm{Bt}$ and non-Bt traits.

Target plant populations were 64220, 79040, 93860, 108680, and 123500 plants $\mathrm{ha}^{-1}$. These plant populations represented increments around the recommended plant population of 74100 plants $\mathrm{ha}^{-1}$, providing a wide range of plant populations for the analysis.

The experimental design at each location was a complete factorial in a randomized complete block with three replications. Except for Arlington in 2004, where the experimental design was a split plot arrangement in a randomized complete block design with three hybrids, where hybrid was a whole-plot factor and plant population a subplot factor replicated three times within the whole-plot.

Plots consisted of four rows (Arlington had eight rows) $6.7 \mathrm{~m}$ long and $0.76 \mathrm{~m}$ apart. Plots were overplanted using a Kinze corn planter mounted with fluted cone units (Kinze Manufacturing, Williamsburg, IA) and hand-thinned at growth stages V5 to V6 (Ritchie et al., 1993) to achieve each target plant population.

Data collected before grain harvest included plant population and stalk-lodged plants. Plants were considered stalklodged if corn stalks were broken below the ear. Percentage lodging was calculated based on the total number of plants stalk-lodged per plot divided by the total number of plants per plot.

The RPR was used to measure rind strength. Three randomly chosen competitive plants per plot were measured with an electronic rind penetrometer, and an average RPR score per plot was reported. The rind penetrometer was a modified Accuforce Cadet digital force gauge, $22.7 \mathrm{~kg}$ capacity, powered by a 9-V alkaline battery (Ametek, Hunter Spring Division, Hatfield, PA). Rind strength was measured by inserting the needle into the internode below the top ear attachment point (Fig. 1), using the flat part of the stalk internode vs. the more rounded portion (Sibale et al., 1992a). The RPR was measured as the maximum force required to puncture the stalk rind.

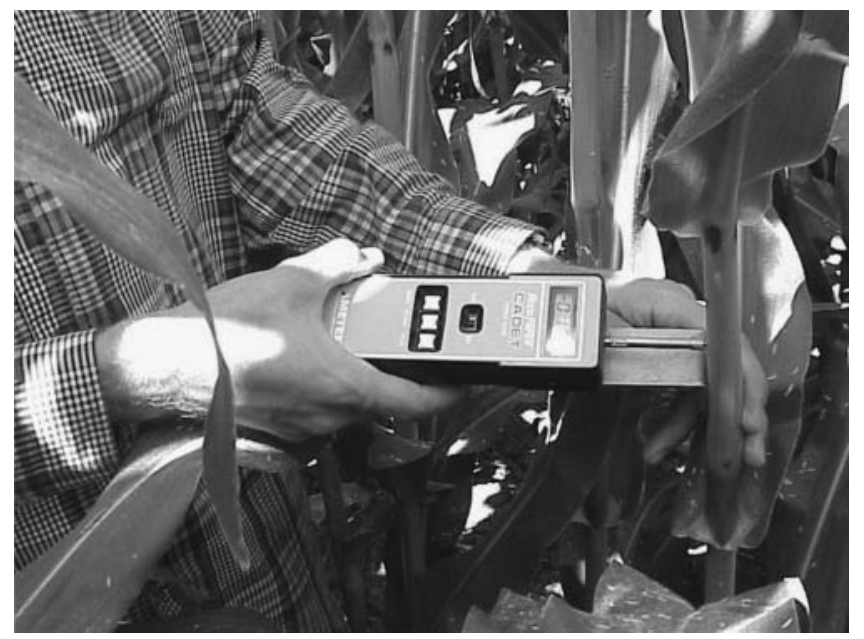

Fig. 1. Measuring rind strength with the modified rind penetrometer in the middle of the internode below the primary ear attachment node. 
Measurements are in load-lbs plant ${ }^{-1}$ (converted to load-kg plant $^{-1}$ for analysis) required to puncture the stalk rind. During 2003, all plant population treatments were measured for RPR, except at Janesville, Hancock, and Chippewa Falls, where only 64220, 93860, and 123500 plants ha ${ }^{-1}$ were tested. During 2004, all plant population treatments were measured.

Rind strength measurements were taken according to recommendations by Larry Darrah (personal communication, 2003). He recommended taking measurements $10 \mathrm{~d}$ after silking for assessing stalk strength, when plants are near the blister stage (R2; Ritchie et al., 1993). Furthermore, two additional rind strength measurements were taken at Arlington to determine the effect of maturity on RPR. These measurements were taken approximately one (R4; dough) and two (R6; physiological maturity) months following the initial measurement.
A vast range of plant populations were reported at harvest which were attributed to many things, namely poor emergence, poor thinning, and tillers. Because of this wide range of plant populations, we used actual plant population data from each individual plot rather than the treatment means. Data were analyzed by analysis of covariance using the PROC MIXED procedure (Littell et al., 1996) of SAS (SAS Inst., 2002). The typical analysis approach for this data would be by location; however, plant population recommendations are wider-ranging than an individual location. Therefore, data were pooled across years by location, zone, and trait (Bt vs. non-Bt). For determining the expected mean squares and appropriate $F$ tests in each analysis of covariance, random effects for the location analysis were year, rep(location $\times$ year), zone $\times$ year, and hybrid(trait); for the zone analysis random effects were

Table 2. Monthly air temperature and rainfall during the 2003 and 2004 growing seasons for 10 locations in Wisconsin.

\begin{tabular}{|c|c|c|c|c|c|c|c|c|c|}
\hline \multirow[b]{3}{*}{ Location $\dagger$} & \multirow[b]{3}{*}{ Month } & \multicolumn{4}{|c|}{2003} & \multicolumn{4}{|c|}{2004} \\
\hline & & \multicolumn{2}{|c|}{ Air temperature } & \multicolumn{2}{|c|}{ Rainfall } & \multicolumn{2}{|c|}{ Air temperature } & \multicolumn{2}{|c|}{ Rainfall } \\
\hline & & Monthly Ave. & Dptr. + & Monthly total & Dptr. & Monthly Ave. & Dptr. & Monthly total & Dptr. \\
\hline & & ${ }^{\circ} \mathrm{C}$ & - & $\longrightarrow \mathrm{cm}$ & - & $-{ }^{\circ} \mathrm{C}-$ & - & $\longrightarrow \mathrm{cm}$ & - \\
\hline \multirow{5}{*}{ Arlington } & May & 13.1 & -0.8 & 9.7 & 1.0 & 13.1 & -0.9 & 26.2 & 17.5 \\
\hline & June & 18.9 & -0.3 & 8.4 & -1.8 & 18.9 & -0.3 & 10.2 & -0.3 \\
\hline & July & 21.7 & 0.3 & 8.4 & -1.5 & 20.3 & -1.1 & 10.9 & 1.3 \\
\hline & August & 22.0 & 1.7 & 4.6 & -6.4 & 17.8 & -2.4 & 7.9 & $-\mathbf{3 . 0}$ \\
\hline & September & 16.1 & 0.2 & 10.2 & 0.8 & 17.9 & 2.1 & 1.3 & -7.9 \\
\hline \multirow[t]{5}{*}{ Chippewa Falls } & May & 13.4 & -1.0 & 11.4 & 2.0 & 12.4 & -2.0 & 16.8 & 7.4 \\
\hline & June & 18.8 & -0.5 & 8.6 & -2.3 & 17.5 & -1.8 & 7.4 & $-\mathbf{3 . 3}$ \\
\hline & July & 21.6 & -0.3 & 8.9 & -1.0 & 20.8 & -1.1 & 5.6 & -4.6 \\
\hline & August & 22.5 & 1.9 & 0.8 & -11.2 & 17.7 & -2.9 & 6.9 & -5.1 \\
\hline & September & 15.7 & 0.4 & 5.3 & -4.1 & 18.3 & 3.1 & 9.4 & -0.3 \\
\hline \multirow{5}{*}{ Fond du Lac } & May & 12.7 & -1.7 & 8.9 & 1.3 & 12.2 & -2.2 & 34.3 & 26.7 \\
\hline & June & 17.7 & -1.8 & 6.9 & -2.0 & 17.2 & -2.3 & 14.5 & 5.3 \\
\hline & July & 20.8 & -1.3 & 10.7 & 1.8 & 19.5 & -2.6 & 6.9 & -2.0 \\
\hline & August & 21.7 & 0.8 & 3.0 & -7.6 & 17.5 & -3.3 & 6.4 & -4.3 \\
\hline & September & 16.1 & -0.2 & 8.4 & -0.5 & 18.6 & 2.2 & 2.5 & -6.4 \\
\hline \multirow[t]{5}{*}{ Galesville } & May & 14.6 & -0.9 & 11.4 & 2.0 & 14.7 & -0.7 & 24.1 & 14.7 \\
\hline & June & 19.3 & -1.0 & 5.8 & -3.8 & 18.6 & -1.8 & 15.0 & 5.3 \\
\hline & July & 22.3 & -0.3 & 5.1 & -5.8 & 21.7 & -1.0 & 16.5 & 5.6 \\
\hline & August & 23.4 & 2.2 & 4.8 & -6.6 & 19.1 & -2.2 & 8.1 & -3.6 \\
\hline & September & 17.2 & 0.7 & 5.8 & -3.8 & 18.9 & 2.4 & 15.0 & 5.1 \\
\hline \multirow[t]{5}{*}{ Hancock } & May & 12.8 & -0.8 & $13.5(3.8) \S$ & 4.8 & 12.6 & -1.0 & $18.3(0)$ & 9.7 \\
\hline & June & 18.4 & -0.3 & $8.6(7.6)$ & -1.0 & 18.0 & -0.7 & $19.6(2.5)$ & 9.9 \\
\hline & July & 20.9 & 0.1 & $5.8(16.0)$ & -4.8 & 20.1 & -0.8 & 9.4 (11.4) & -1.3 \\
\hline & August & 21.9 & 2.3 & 1.8 (17.3) & -9.1 & 17.8 & -1.8 & $7.4(8.9)$ & -3.6 \\
\hline & September & 16.3 & 1.3 & $7.4(5.1)$ & -1.8 & 19.5 & 4.5 & $1.3(3.3)$ & -7.9 \\
\hline \multirow{5}{*}{ Janesville } & May & 13.5 & -1.4 & 20.8 & 12.2 & 14.9 & 0.0 & 20.6 & 11.9 \\
\hline & June & 18.7 & -1.7 & 6.4 & -5.3 & 19.2 & -1.2 & 13.0 & 1.3 \\
\hline & July & 22.2 & -0.3 & 13.0 & 3.3 & 21.1 & -1.4 & 4.3 & -5.3 \\
\hline & August & 23.3 & 2.1 & 2.8 & -8.1 & 19.2 & -2.0 & 8.9 & -2.0 \\
\hline & September & 17.5 & 0.7 & 6.6 & -2.8 & 19.1 & 2.2 & 0.8 & -8.4 \\
\hline \multirow[t]{5}{*}{ Lancaster } & May & 13.2 & -1.1 & 16.0 & 6.6 & 13.8 & -0.4 & 27.9 & 18.5 \\
\hline & June & 18.4 & -1.0 & 8.1 & -4.1 & 18.4 & -0.9 & 12.4 & 0.3 \\
\hline & July & 21.4 & -0.3 & 8.9 & -1.5 & 20.2 & -1.5 & 10.2 & -0.3 \\
\hline & August & 22.7 & 2.2 & 1.8 & -9.9 & 17.8 & -2.7 & 9.1 & -2.5 \\
\hline & September & 16.3 & 0.5 & 7.4 & -0.8 & 18.1 & 2.3 & 0.3 & -7.9 \\
\hline \multirow[t]{5}{*}{ Marshfield } & May & 12.6 & -0.6 & 9.9 & 0.5 & 11.6 & -1.7 & 22.1 & 12.7 \\
\hline & June & 17.6 & -0.9 & 7.1 & -3.3 & 16.8 & -1.7 & 10.7 & 0.0 \\
\hline & July & 20.4 & -0.6 & 3.8 & -6.4 & 19.9 & -1.1 & 4.8 & -5.6 \\
\hline & August & 21.6 & 2.1 & 2.3 & -8.6 & 16.8 & -2.7 & 6.4 & -4.6 \\
\hline & September & 15.7 & 1.4 & 5.6 & -4.6 & 17.6 & 3.3 & 4.1 & -6.1 \\
\hline \multirow{5}{*}{ Seymour } & May & 11.7 & -1.8 & 8.1 & 1.0 & 12.0 & -1.6 & 21.1 & 14.2 \\
\hline & June & 17.3 & -1.2 & 9.4 & 0.8 & 17.4 & -1.2 & 12.4 & 3.6 \\
\hline & July & 19.9 & -1.1 & 10.9 & 2.0 & 19.8 & -1.3 & 4.6 & -4.3 \\
\hline & August & 20.6 & 0.9 & 10.7 & 1.0 & 17.9 & -1.8 & 5.1 & -4.6 \\
\hline & September & 15.9 & 1.1 & 8.4 & 0.5 & 18.1 & 3.2 & 1.3 & -6.6 \\
\hline Valders & May & 9.8 & -2.8 & 10.7 & 3.6 & 11.1 & -1.4 & 22.1 & 15.0 \\
\hline & June & 16.3 & -1.5 & 8.1 & -0.3 & 16.6 & -1.3 & 9.7 & 1.3 \\
\hline & July & 20.4 & -0.6 & 6.1 & -2.8 & 18.8 & -2.2 & 7.6 & -1.0 \\
\hline & August & 21.4 & 1.1 & 8.6 & -1.0 & 18.1 & -2.2 & 6.4 & $-\mathbf{3 . 3}$ \\
\hline & September & 16.0 & 0.1 & 5.6 & -2.3 & 17.7 & 1.7 & 1.3 & -6.6 \\
\hline
\end{tabular}

$\dagger$ Southern zone $=$ Arlington, Janesville, and Lancaster; South Central zone $=$ Fond du Lac, Galesville, and Hancock; North Central zone $=$ Chippewa Falls Marshfield, Seymour, and Valders.

$\doteqdot$ Dptr. = departure from 40 -yr average.

$\S$ Hancock is an irrigated location. Monthly irrigation totals are in parentheses. 
year, location(year), rep(location $\times$ year), and hybrid(trait); and for the overall analysis random effects were year, location(zone $\times$ year), rep $\times$ location(zone $\times$ year), hybrid(trait).

In the Arlington data set, for the analysis of RPR over time (within a growing season), the covariate was plant population at harvest. Repeated measures analysis (SAS Inst., 2002), with the compound symmetry variance structure, was used to evaluate time effects on rind strength. The random effects for this analysis were year and hybrid(trait). To compensate for the difference in experimental designs between 2003 and 2004, treatment means were used instead of individual plot data with year being used as a replicate.

For each analysis above, manual backward elimination was used to determine which factors (i.e., location, zone, trait, plant population, and growth stage) were most useful for predicting RPR and stalk lodging. This technique starts with all factors and interactions among factors as potential predictor variables and sequentially deletes nonsignificant interactions and main factors. The factor producing the smallest $F$ value is deleted at each stage and the model is complete when each factor remaining in the model has a value of $P \leq 0.05$. The aim of this procedure was to include in the regression equation only those terms that contribute significantly to the variation in the dependent variable (Gomez and Gomez, 1984).

Least square means of the fixed effects were computed, and the PDIFF option of the LSMEANS statement was used to distinguish differences among least square means of fixed effects (i.e., trait, location, zone, and growth stage). This option uses Fisher's protected LSD, and comparison was conducted at $P \leq 0.05$. The coefficient of determination $\left(R^{2}\right)$ was derived using the predicted values calculated by PROC MIXED, $R^{2}=$ $1-\left\{\left[y_{i j}-\hat{y}_{(\text {Pred })}\right]^{2} /\left[y_{i j}-y_{\text {(grand mean })}\right]^{2}\right\}$.

\section{RESULTS AND DISCUSSION}

The results and discussion in this paper will not cover grain yield response to increasing plant population and the Bt trait. However, a thorough agronomic and economic analysis on grain yield in relation to plant population and the Bt trait can be found in a companion paper (Stanger and Lauer, 2006).

Monthly average air temperature and rainfall for the 2003 and 2004 growing seasons (May-September) are included in Table 2. In 2003, mean air temperature was consistently below the 40-yr average during May, June, and July, and air temperatures in August and September were above the 40-yr average. Rainfall during the growing season was below the 40-yr average at all locations except Seymour. Emerged stands at Marshfield and Valders were poor due to cold, wet spring conditions at Marshfield and heavy soil crusting at Valders. In 2004, temperatures were cooler than the 40-yr average during May, June, July, and August, while September air temperatures were well above the 40-yr average. Rainfall was well above the 40-yr average during May and below average the remainder of that season, except for Galesville, which was above average for rainfall every month except August, where it was below average. Record rainfalls occurred following planting at Seymour and Valders, reducing stands. At Fond du Lac, wet field conditions after planting severely affected corn emergence, development, and subsequent stand establishment, causing this location to be dropped from the analysis for 2004.
Table 3. Average number of European Corn Borer plant ${ }^{-1}$ during the fall of 2003 and 2004 for 10 counties (locations) in Wisconsin. $\dagger$

\begin{tabular}{lll}
\hline County (location) & 2003 & 2004 \\
\hline Chippewa (Chippewa Falls) & 0.39 & 0.06 \\
Columbia (Arlington) & 1.22 & $\mathbf{0 . 1 2}$ \\
Fond du Lac (Fond du Lac) & $\mathbf{0 . 5 0}$ & $\mathbf{0 . 4 3}$ \\
Grant (Lancaster) & $\mathbf{0 . 0 0}$ & $\mathbf{0 . 1 9}$ \\
Manitowoc (Valders) & $\mathbf{0 . 0 0}$ & $\mathbf{0 . 1 7}$ \\
Outagamie (Seymour) & $\mathbf{0 . 3 1}$ & $\mathbf{0 . 3 3}$ \\
Rock (Janesville) & $\mathbf{0 . 1 6}$ & $\mathbf{0 . 0 1}$ \\
Trempealeau (Galesville) & $\mathbf{0 . 2 1}$ & $\mathbf{0 . 1 4}$ \\
Waushara (Hancock) & $\mathbf{0 . 0 9}$ & $\mathbf{0 . 0 1}$ \\
Wood (Marshfield) & $\mathbf{0 . 2 3}$ & $\mathbf{0 . 1 0}$ \\
\hline
\end{tabular}

$\dagger$ Data were collected by the Wisconsin Department of Agriculture, Trade and Consumer Protection.

European corn borer was present during this study (Table 3), but levels were low and minimal damage was noted due to insect feeding. Thus, ECB was not considered to be a concern. Stalk lodging severity varied considerably depending on environment. The majority of the stalk-lodged plants were associated with stalk rot pathogens that were more severe in some environments than others.

\section{Rind Penetrometer Resistance and Stalk Lodging}

The significance of $F$ values attained from the analyses of covariance for RPR and stalk lodging are shown in Table 4. The quadratic coefficient of plant population was significant in all data pools for RPR (Table 4). The RPR did not decrease proportional to an increase in

Table 4. Significance of $F$ values from analysis of covariance of rind penetrometer resistance (RPR) and stalk lodging during 2003-2004. Data were pooled by location, zone, and overall.

\begin{tabular}{|c|c|c|}
\hline Source of variation & RPR & Stalk lodging \\
\hline \multicolumn{3}{|l|}{ Location } \\
\hline Trait (T) & $\mathbf{N S} \dagger$ & NS \\
\hline Location (L) & $*$ & NS \\
\hline $\mathbf{T} \times \mathbf{L}$ & NS & $* * *$ \\
\hline Harvest plant population (P) & **** & $* * *$ \\
\hline $\mathbf{P} \times \mathbf{T}$ & NS & NS \\
\hline $\mathbf{P} \times \mathbf{L}$ & NS & **** \\
\hline $\mathbf{P} \times \mathbf{T} \times \mathbf{L}$ & NS & NS \\
\hline & $* *$ & NS \\
\hline $\mathbf{P}_{2}^{2} \times \mathbf{T}$ & NS & NS \\
\hline $\mathbf{P}^{2} \times \mathbf{L}$ & NS & NS \\
\hline $\mathbf{P}^{2} \times \mathbf{T} \times \mathbf{L}$ & NS & NS \\
\hline \multicolumn{3}{|l|}{ Zone } \\
\hline $\mathbf{T}$ & NS & NS \\
\hline Zone (Z) & NS & $* *$ \\
\hline $\mathbf{T} \times \mathbf{Z}$ & NS & **** \\
\hline $\mathbf{P}$ & $* * *$ & * \\
\hline $\mathbf{P} \times \mathbf{T}$ & NS & NS \\
\hline $\mathbf{P} \times \mathbf{Z}$ & NS & ** \\
\hline $\mathbf{P} \times \mathbf{T} \times \mathbf{Z}$ & NS & NS \\
\hline & $* *$ & NS \\
\hline $\mathbf{P}^{2} \times \mathbf{T}$ & NS & NS \\
\hline $\mathbf{P}^{2} \times Z$ & NS & $*$ \\
\hline $\mathbf{P}^{2} \times \mathbf{T} \times \mathbf{Z}$ & NS & NS \\
\hline \multicolumn{3}{|l|}{ Overall } \\
\hline $\mathbf{T}$ & NS & NS \\
\hline $\mathbf{P}$ & $* * *$ & NS \\
\hline $\mathbf{P}_{2} \times \mathbf{T}$ & NS & NS \\
\hline $\begin{array}{l}\mathbf{P}^{2} \\
\mathbf{P}^{2} \times T\end{array}$ & $\begin{array}{r}* * \\
\text { NS }\end{array}$ & $\begin{array}{l}* * \\
\text { NS }\end{array}$ \\
\hline $\mathbf{P}^{2} \times \mathbf{T}$ & NS & NS \\
\hline
\end{tabular}

* Significant at the 0.05 level.

** Significant at the 0.01 level.

$* * *$ Significant at the 0.001 level.

$\dagger$ NS, no significant differences at $P \leq \mathbf{0 . 0 5}$. 


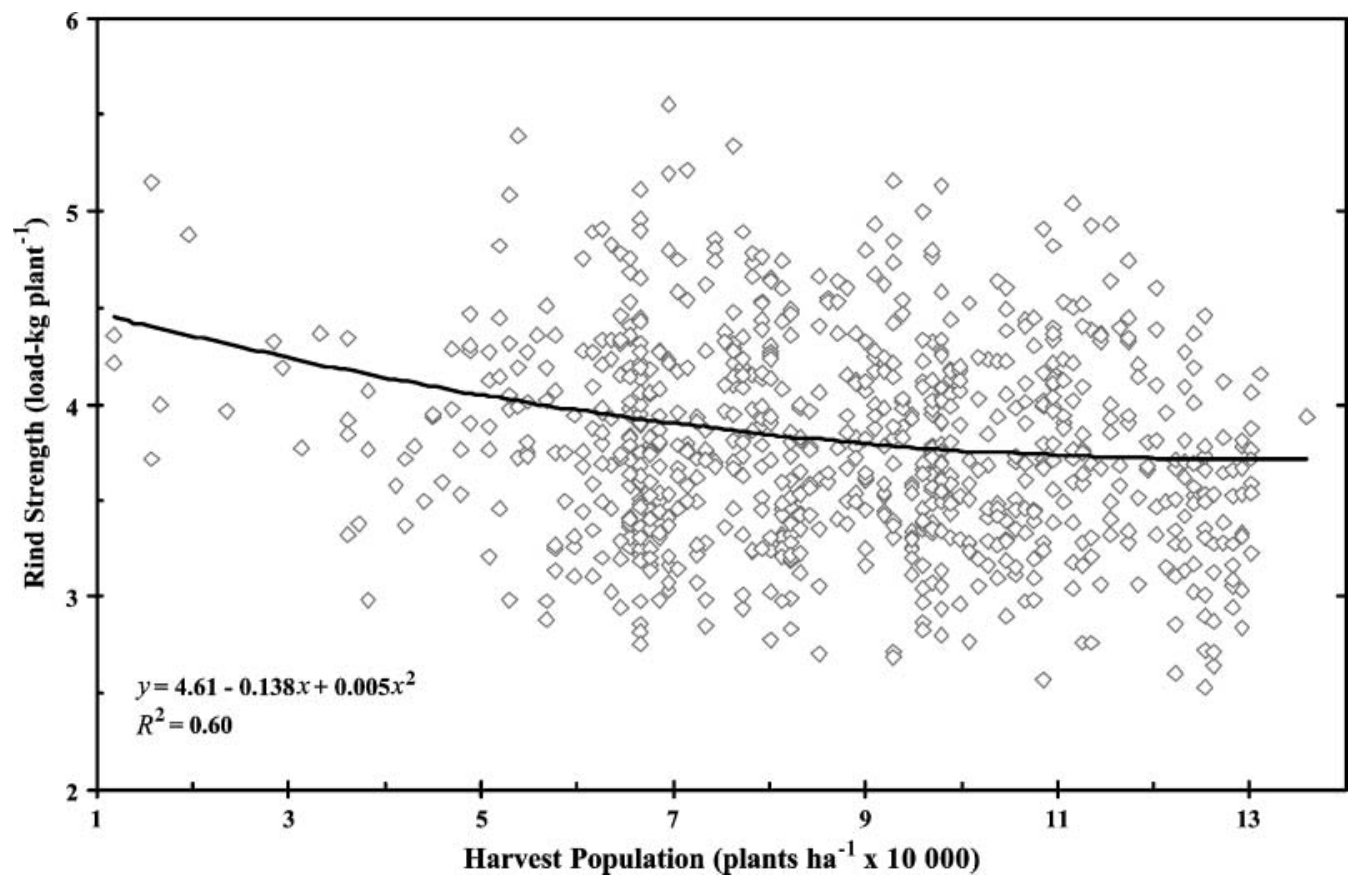

Fig. 2. The relationship between plant population and rind penetrometer resistance in Wisconsin during 2003-2004. Points represent individual plots.

plant population, but decreased at a slower rate (Fig. 2). Overall, RPR decreased $6 \%$ from 3.9 to 3.7 load-kg plant $^{-1}$ as harvest plant population increased from 64220 to 123500 plants ha ${ }^{-1}$, respectively (Fig. 2). Similarly, Jampatong et al. (2000) observed that RPR decreased $8 \%$ with increasing plant populations. Overall, RPR at the current Wisconsin recommendation of 74100 plants ha ${ }^{-1}$ averaged 3.9 load-kg plant ${ }^{-1}$. The RPR varied by location (Table 4), ranging from 4.1 load-kg plant $^{-1}$ at Valders to 3.6 load-kg plant ${ }^{-1}$ at Hancock. The overall average RPR was 3.8 load-kg plant ${ }^{-1}$. These differences may be attributed to a variety of factors including soil, weather, and possible hybrid influence. Each analysis also indicated that there was no difference in RPR between Bt and non-Bt hybrids. It appears that the ability of $\mathrm{Bt}$ hybrids to resist lodging is not due to

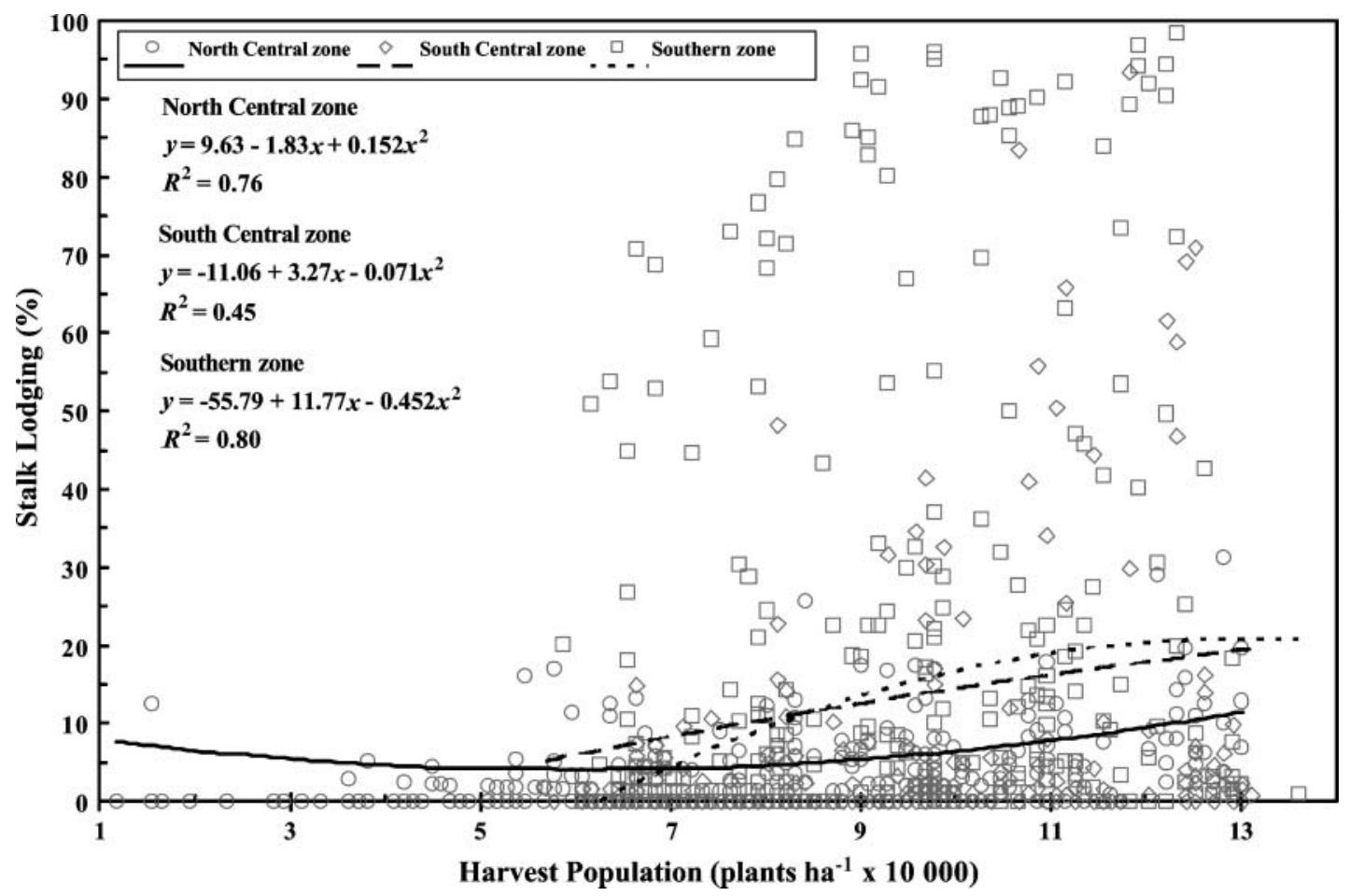

Fig. 3. The relationship between plant population and stalk lodging by each zone in Wisconsin during 2003-2004. Points represent individual plots. 
Table 5. Significance of $\boldsymbol{F}$ values from repeated measures analysis of rind penetrometer resistance (RPR) across time at Arlington. Data were pooled across years, 2003-2004.

\begin{tabular}{lc}
\hline Source of variation & $\mathbf{R P R}$ \\
\hline Trait $(\mathbf{T})$ & $\mathbf{N S} \dagger$ \\
Growth Stage (G) & $* * *$ \\
$\mathbf{T} \times \mathbf{G}$ & $\mathbf{N S}$ \\
$\mathbf{H a r v e s t}$ plant population (P) & $* *$ \\
$\mathbf{P} \times \mathbf{T}$ & $\mathbf{N S}$ \\
$\mathbf{P} \times \mathbf{G}$ & $\mathbf{N S}$ \\
$\mathbf{P} \times \mathbf{T} \times \mathbf{G}$ & $\mathbf{N S}$ \\
$\mathbf{P}^{2}$ & $* \mathbf{T}$ \\
$\mathbf{P}^{2} \times \mathbf{T}$ & $\mathbf{N S}$ \\
$\mathbf{P}^{2} \times \mathbf{G}$ & $\mathbf{N S}$ \\
$\mathbf{P}^{2} \times \mathbf{T} \times \mathbf{G}$ & $\mathbf{N S}$ \\
\hline
\end{tabular}

* Significant at the 0.05 level.

** Significant at the 0.01 level.

$* * *$ Significant at the 0.001 level.

$\dagger \mathrm{NS}$, no significant differences at $\boldsymbol{P} \leq \mathbf{0 . 0 5}$.

superior rind strength, but to some other trait linked to its ability to resist insect feeding.

European corn borer present during this study caused minimal damage. Rind penetrometer resistance results may have been different if ECB pressure had been severe and stalk damage significant. For Wisconsin, this remains unanswered and future work will elucidate the impact of ECB on RPR measurements.

Stalk lodging was influenced by harvest plant population (Table 4). We observed a significant quadratic interaction with plant population $\times$ zone as well as significant interactions with plant population $\times$ location and plant population $\times$ zone (Tables 4 and Fig. 3). As harvest plant population increased from 64220 to 123500 plants $\mathrm{ha}^{-1}$, stalk lodging in the Southern zone ranged from 1 to $21 \%$ and in the North Central zone from 4 to $10 \%$. We saw very little stalk lodging at Janesville, Lancaster, and Marshfield compared with increased stalk lodging measured at Galesville from 6 to $32 \%$ and at Arlington from 18 to $54 \%$. Some of this lodging variability was attributed to stalk rot that was more severe at some locations than others. Overall, an increase in harvest plant population from 64220 to 123500 plants $\mathrm{ha}^{-1}$ increased stalk lodging from 6 to $18 \%$ (Fig. 3) with $7 \%$ stalk lodging at the current Wisconsin recommendation of 74100 plants ha $^{-1}$. This study confirmed other reports where an increase in stalk lodging was observed with plant population increases (Moentono et al., 1984; Thomison and Jordan, 1995; Jampatong et al., 2000; Pedersen and Lauer, 2002; Bruns and Abbas, 2005; Stanger and Lauer, 2006). Significant trait $\times$ location and trait $\times$ zone interactions were also observed for stalk lodging (Table 4). At Arlington and in the Southern zone, non-Bt hybrids had greater stalk lodging than Bt hybrids (42 vs. $20 \%$ and 16 vs. $3 \%$, respectively). Overall, stalk lodging for Bt and nonBt hybrids was 6 and 13\%, respectively. Lauer and

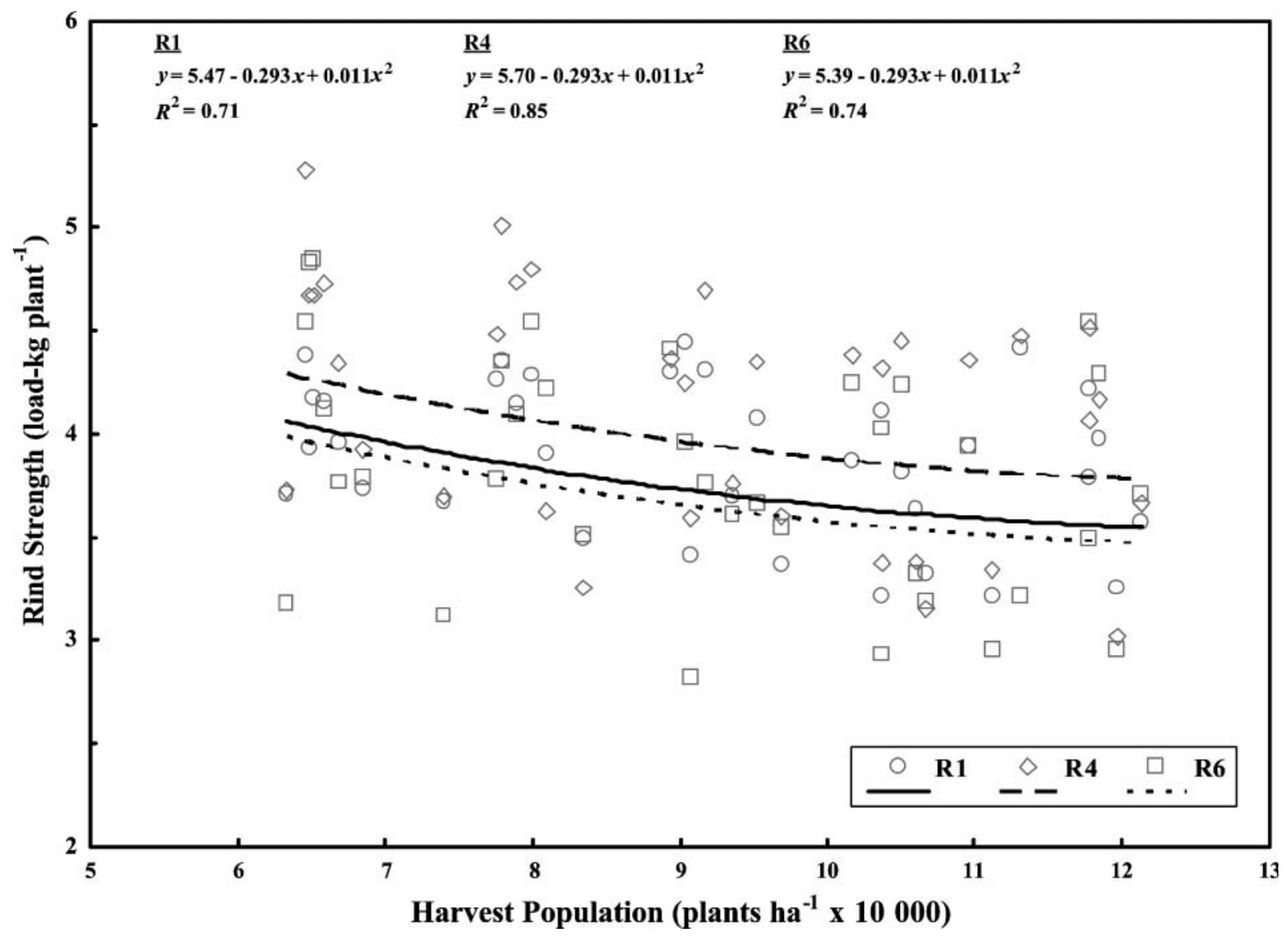

Fig. 4. The relationship between plant population and rind penetrometer resistance when measured at three corn growth stages at Arlington, WI, during 2003-2004. Points represent treatment means for each year. 
Wedberg (1999) and Graeber et al. (1999) found similar results regarding $\mathrm{Bt}$ and non-Bt hybrid effects on lodging percentage.

Overall, as harvest plant population increased from 64220 to 123500 plants ha ${ }^{-1}$, RPR decreased from 3.9 to 3.7 load-kg plant $^{-1}$ (Fig. 2), while stalk lodging increased from 6 to $18 \%$ (Fig. 3). These results indicate that RPR measurements $<3.9$ load-kg plant ${ }^{-1}$ appear to be a good indicator of stalk lodging potential in a high plant population situation taken at physiological maturity, because RPR measurements $<3.9$ load-kg plant $^{-1}$ are more prone to lodging. However, further research is necessary to fully understand the importance of this tool and its potential importance in understanding and identifying high lodging potential environments.

\section{Rind Penetrometer Resistance across Time}

At Arlington, RPR was significant for the harvest plant population and growth stage at measurement (Table 5). The RPR decreased from 4.1 to 3.6 load-kg plant $^{-1}$ as plant population increased from 64220 to 123500 plants ha ${ }^{-1}$, respectively (Fig. 4), which corresponds with what was observed previously (see Fig. 1). The quadratic coefficient of plant population showed significance also (Table 5), again demonstrating that RPR decreased at a slower rate at higher plant populations.

Currently, no data have been published on the effect of growth stage following silking on RPR. According to these results, the time for assessing maximum RPR is not $10 \mathrm{~d}$ following silking, but much later. Measurements taken at the dough stage (R4) averaged 0.2 load-kg plant $^{-1}$ more than the measurements taken on the date recommended (Fig. 4). According to Ritchie et al. (1993), the stalk continues to accumulate dry matter up to the R4 stage and begins to decline shortly thereafter. Our observations showed similar results with rind strength. Because of this and the potential for increased incidence of stalk rot, we recommend that rind strength measurements be taken at physiological maturity for a true assessment of stalk lodging potential before grain harvest.

\section{CONCLUSIONS}

Stalk lodging increased with the higher plant populations in all locations. Only in one location, Arlington, Bt hybrids stalk-lodged less when compared with non-Bt hybrids. Although there was no difference in RPR between hybrids with or without the Bt trait, RPR decreased with increasing plant population. Rind penetrometer resistance measurements $<3.9$ load-kg plant ${ }^{-1}$ showed more lodging and were a good indicator of stalk lodging potential in a high plant population situation taken at physiological maturity. This new method has potential to help growers prepare for grain harvest by identifying fields with plants having average RPR below a 3.9 load-kg plant ${ }^{-1}$ threshold, and adjusting harvest schedules of suspect fields earlier to avoid yield losses caused by stalk lodging. Further research using more hybrids across a range of environmental conditions and plant populations will be necessary to fully understand the importance of this tool and its potential importance in understanding and identifying high lodging potential environments.

\section{ACKNOWLEDGMENTS}

The authors thank Dr. Larry Darrah, USDA-ARS-Columbia, MO, for sharing his valuable knowledge in rind strength and for the use of his rind penetrometer. We acknowledge the contribution of research specialists Kent Kohn and Pat Flannery for their technical assistance; Jung Won Mun for her assistance in data analysis; and to the associate editor and reviewers for the helpful comments. Funding for this research and publication was provided from the USDA Cooperative State Research, Education and Extension Service (CSREES) project WIS0 142-4897.

\section{REFERENCES}

Armstrong, C.L., G.B. Parker, J.C. Pershing, S.M. Brown, P.R. Sanders, D.R. Duncan, T. Stone, D.A. Dean, et al. 1995. Field evaluation of European corn borer control of progeny of 173 transgenic corn events expressing an insecticidal protein from Bacillus thuringiensis. Crop Sci. 35:550-557.

Berzonsky, W.A., J.A. Hawk, and T.D. Pizzolato. 1986. Anatomical characteristics of three inbred lines and two maize synthetics recurrently selected for high and low stalk strength. Crop Sci. 26:482-488.

Bruns, H.A., and H.K. Abbas. 2004. Effects of harvest date on maize in the humid sub-tropical mid-south USA. Maydica 49:1-7.

Bruns, H.A., and H.K. Abbas. 2005. Ultra-high plant populations and nitrogen fertility effects on corn in the Mississippi valley. Agron. J. 97:1136-1140.

Chesang-Chumo, J. 1993. Direct and correlated responses to divergent selection for rind penetrometer resistance in MoSCSSS maize synthetic (Zea mays). Ph.D. thesis. Univ. of Missouri, Colombia.

Cox, W.J. 1997. Corn silage and grain yield responses to plant densities. J. Prod. Agric. 10:405-410.

Foley, D.C., and R.L. Clark. 1984. Mechanical properties of maize stalks from the plant introduction collection. Crop Sci. 24:1116-1118.

Gomez, K.A., and A.A. Gomez. 1984. Statistical procedures for agricultural research. 2nd ed. John Wiley \& Sons, New York.

Graeber, J.V., E.D. Nafziger, and D.W. Mies. 1999. Evaluation of transgenic, Bt-containing corn hybrids. J. Prod. Agric. 12:659-663.

Jampatong, S., L.L. Darrah, G.F. Krause, and B.D. Barry. 2000. Effect of one- and two-eared selection on stalk strength and other characters in maize. Crop Sci. 40:605-611.

Koziel, M.G., G.L. Beland, C. Bowman, N.B. Carozzi, R. Crenshaw, L. Crossland, J. Dawson, N. Desai, M. Hill, S. Kadwell, et al. 1993. Field performance of elite transgenic maize plants expressing an insecticidal protein derived from Bacillus thuringiensis. Biotechnology 11(2):194-200.

Lauer, J.G., and J. Wedberg. 1999. Grain yield of initial Bt corn hybrid introductions to farmers in the northern corn belt. J. Prod. Agric 12:373-376.

Littell, R.C., G.A. Milliken, W.W. Stroup, and W.W. Wolfinger. 1996. SAS system for mixed models. SAS Institute, Cary, NC.

Martin, S.A., L.L. Darrah, and B.E. Hibbard. 2004. Divergent selection for rind penetrometer resistance and its effects on European corn borer damage and stalk traits in corn. Crop Sci. 44: 711-717.

Masole, H. 1993. Evaluation of high and low divergent rind penetrometer resistance selection at three plant densities in maize. M.S. thesis. Univ. of Missouri, Colombia.

Moentono, M.D., L.L. Darrah, M.S. Zuber, and G.F. Krause. 1984 Effects of selection for stalk strength on responses to plant density and level of nitrogen application in maize. Maydica 29:431-452.

Monneveux, P., P.H. Zaidi, and C. Sanchez. 2005. Population density and low nitrogen affects yield-associated traits in tropical maize. Crop Sci. 46:180-191.

Olson, R.A., and D.H. Sander. 1988. Corn production. p. 639-686. In G.F. Sprague and J.W. Dudley (ed.) Corn and corn improvement. ASA, CSSA, and SSSA, Madison, WI. 
Pedersen, P., and J.G. Lauer. 2002. Influence of rotation sequence on the optimum corn and soybean plant population. Agron. J. 94:968-974.

Ritchie, S.W., J.J. Hanway, and G.O. Benson. 1993. How a corn plant develops. Rep. 48. Iowa St. Coop. Ext., Iowa St. Univ., Ames.

SAS Institute. 2002. SAS release 9.1. The SAS Inst., Cary, NC.

Seydou, B.T., R.E. Carlson, C.D. Pilcher, and M.E. Rice. 2000. Bt and non-Bt maize growth and development as affected by temperature and drought stress. Agron. J. 92:1027-1035.

Sibale, E.M., L.L. Darrah, and M.S. Zuber. 1992a. Comparison of two rind penetrometers for measurement of stalk strength in maize. Maydica 37:111-114.

Sibale, E.M., L.L. Darrah, M.S. Zuber, and D.A. Sleper. 1992 b.
Correlated responses to selection for stalk crushing strength in two maize populations. Maydica 37:115-122.

Stanger, T.F., and J.G. Lauer. 2006. Optimum plant population of Bt and non-Bt corn in Wisconsin. Agron. J. 98:914-921.

Thomison, P.R., and D.M. Jordan. 1995. Plant population effects on corn hybrids differing in ear growth habit and prolificacy. J. Prod. Agric. 8:394-400.

Troyer, A.F., and R.W. Rosenbrook. 1983. Utility of higher plant densities for corn performance testing. Crop Sci. 23:863-867.

VanGessel, M.J., E.E. Schweizer, D.W. Lybecker, and P. Westra. 1995. Compatibility and efficiency of in-row cultivation for weed management in corn. Weed Technol. 9:754-760. 